\title{
NEW PREY ITEM IN THE DIET OF MASTICOPHIS SCHOTTI BAIRD \& GIRARD, 1853 FROM SAN LUIS POTOSÍ, MEXICO
}

\section{UN NUEVO TIPO DE PRESA EN LA DIETA DE MASTICOPHIS SCHOTTI BAIRD \& GIRARD, 1853 DE SAN LUIS POTOSÍ, MÉXICO}

\author{
Rubén Alonso Carbajal-MárqueZ ${ }^{1,4 *}$, Gustavo Ernesto Quintero-DíaZ ${ }^{2,4}$, Guillermo MartíneZ-De la \\ VEGA $^{3,4}$ AND AURELIO GONZÁLEZ \\ ${ }^{1}$ El Colegio de la Frontera Sur, Departamento de Sistemática y Ecología Acuática, Unidad Chetumal, Avenida Centenario Km 5.5, C.P. 77014 Chetumal, \\ Quintana Roo, México. \\ ${ }^{2}$ Universidad Autónoma de Aguascalientes, Centro de Ciencias Básicas, Departamento de Biología. C. P. 20131, Aguascalientes, Aguascalientes, \\ México. \\ ${ }^{3}$ Instituto de Investigación de Zonas Desérticas de la Universidad Autónoma de San Luis Potosí, Altair No. 200, Fracc. Del Llano, C.P. 78377, San Luis \\ Potosí, SLP, México. \\ ${ }^{4}$ Conservación de la Biodiversidad del Centro de México, A.C. Andador Torre de Marfil No. 100, C.P. 20229, Aguascalientes, Aguascalientes, México. \\ *Correspondence: redmano31@hotmail.com
}

Resumen.- Reportamos la lagartija Sceloporus torquatus como una presa natural de Masticophis schotti en San Luis Potosí, México. Aunque se conoce que M. schotti se alimenta de las lagartijas del género Sceloporus, este es el primer registro de $S$. torquatus en la dieta de esta culebra.

Palabras clave.- Colubridae, Phrynosomatidae, San Luis Potosí, Sceloporus, México.

Abstract.- We report Sceloporus torquatus as natural prey of Masticophis schotti in San Luis Potosí, México. Although M. schotti is known to eat lizards of the genus Sceloporus, this is the first record of $S$. torquatus in the diet of this snake.

Keywords.- Colubridae, Phrynosomatidae, San Luis Potosí, Sceloporus, Mexico.

Schott's whipsnake (Masticophis schotti Baird \& Girard, 1835) ranges from central Texas in the USA south through the Gulf coastal plains to central Veracruz, Mexico, and on the Mexican Plateau from Hidalgo to Michoacán, with a vertical distribution from near sea level to around $2,500 \mathrm{~m}$. Two subspecies are currently recognized (Camper \& Dixon, 1994; Camper, 1996): Masticophis s. schotti Baird \& Girard, 1835 occurs from Texas to extreme northwestern Tamaulipas, central Nuevo León and eastern Coahuila, Mexico, whereas Masticophis s. ruthveni (Ortenburger, 1923) ranges from the southern tip of Texas to through Tamaulipas, northern and central Veracruz, San Luis Potosí, Hidalgo, Querétaro, Guanajuato, to northern Michoacán, Mexico (Werler \& Dixon, 2000; Ernst \& Ernst, 2003; LemosEspinal \& Dixon, 2013; Heimes, 2016). Masticophis schotti is a long, slender, fast and agile snake that reaches $1900 \mathrm{~mm}$ in total length (Ernst \& Ernst, 2003; Lemos-Espinal \& Dixon, 2013; Heimes 2016). The species is listed in the Red List of IUCN as a taxon of least concern (LC), and in the medium vulnerability category (13) in the Environmental Vulnerability Score (Hammerson et al.,
2007; Wilson et al., 2013), but was not considered in any peril category by the Mexican law in the NOM-059-SEMARNAT-2010 (Diario Oficial de la Federación 2010).

Masticophis schotti is an active diurnal species that forages with its head and forebody raised above the ground (Ernst \& Ernst, 2003). Examination of 316 museum specimens of M. schotti revealed that only $5 \%$, had stomach contents, representing eight prey species (Camper \& Dixon, 2000). Lizards (18, 78.3\%) were the most frequent prey category, followed by mammals (5, 21.7\%), which were only consumed by larger specimens. Masticophis schotti ingested $85.7 \%$ of its prey head-first, indicating that they may manipulate prey prior to ingesting it. Lemos-Espinal \& Dixon (2013) mentions that the diet of M. schotti consists of lizards of the families Anguidae, Crotaphytidae, Dactyloidae, Phrynosomatidae, Scincidae, and Teiidae, based on Camper and Dixon (2002; with a mistake in the year of publication), and differs from the information provided by Camper and Dixon (2000) where only report Phrynosomatidae (Sceloporus), 


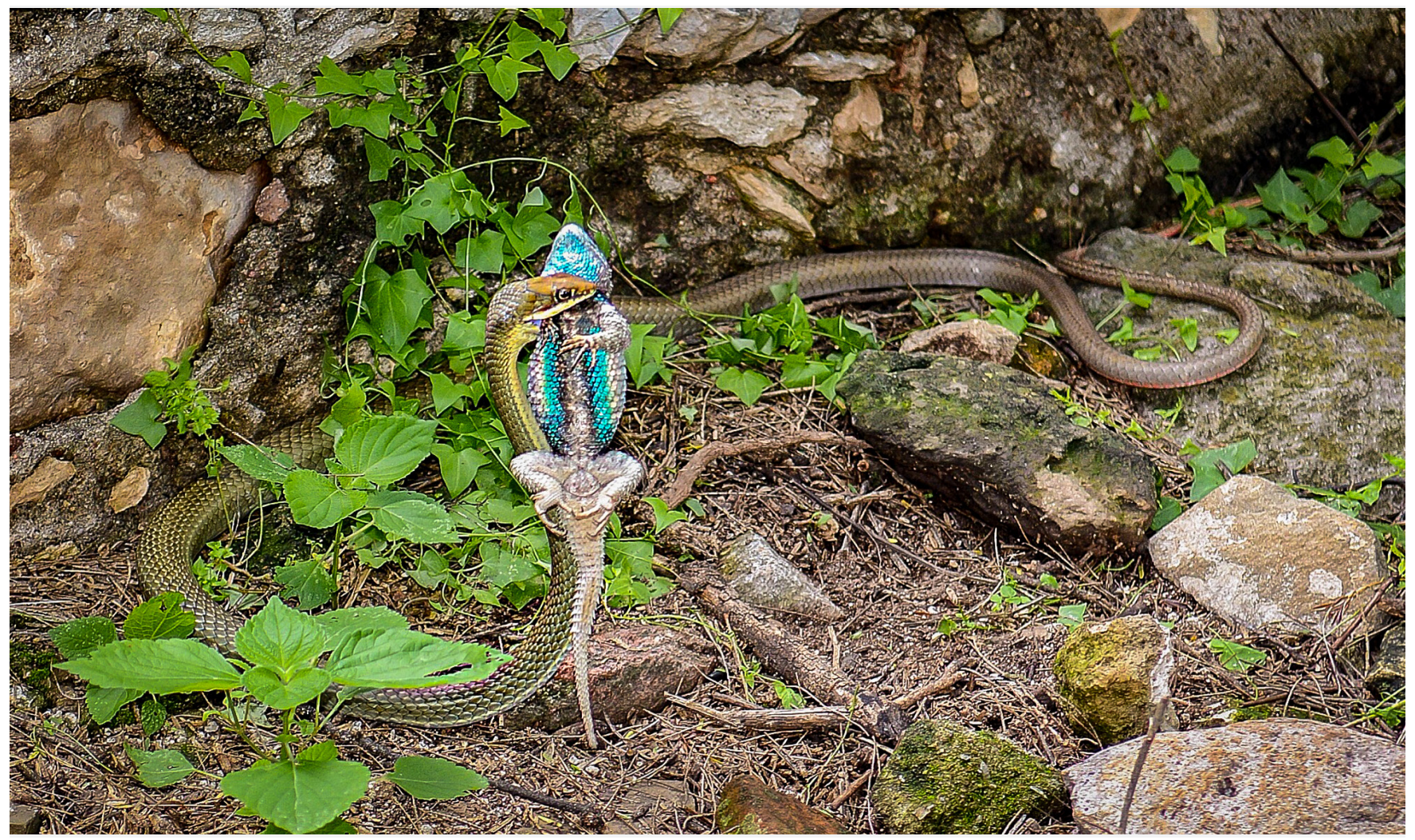

Figura 1. Individuo de Masticophis schotti ruthveni sosteniendo un macho de Sceloporus torquatus antes de consumirlo en la ex-Hacienda La Parada, San Luis Potosí, México. Foto: Aurelio González.

Figure 1. A Masticophis schotti ruthveni holding a male Sceloporus torquatus before consuming it, at ex-Hacienda La Parada, San Luis Potosí, Mexico. Photo: Aurelio González.

Dactyloidae (Anolis), Scincidae (Plestiodon and Scincella), Teiidae (Aspidocelis), and unidentified lizards.

On 05 July 2015 at $1030 \mathrm{~h}$, we observed and photographed a Masticophis schotti ruthveni while capturing and consuming a male Sceloporus torquatus (Torquate lizard) in xerophytic scrub vegetation in ex-Hacienda La Parada, on Km. 35 San Luis Potosí - Zacatecas Highway, Ahualulco, San Luis Potosí, Mexico $\left(22.330786^{\circ} \mathrm{N}, 101.206714^{\circ} \mathrm{W}\right.$; WGS 84 datum; elev. $1874 \mathrm{~m}$; Fig. 1). We did not take additional data on the snake or the prey, to avoid disturbing the predatory event. The snake captured the lizard, and upon noticing our presence, the snake raised the first third of its body while moving to a secluded place to consume its prey, which was swallowed head-first. Figure 1 shows the snake holding the lizard by the neck, consistent with the aforementioned observation that $M$. schotti manipulates its prey before ingesting it (Camper \& Dixon, 2000). This note represents the first record of Sceloporus torquatus in the diet of M. s. ruthveni, and also demonstrates the need for a systematic study to elucidate the ecology of the southern populations of this species.

Acknowledgements.- We thank to Jeff D. Camper for review a previous draft of the manuscript.

\section{CITED LITERATURE}

Camper, J.D. 1996. Masticophis schotti. Catalogue of American Amphibians and Reptiles. Society for the Study of Amphibians and Reptiles 638.1-638.4.

Camper, J.D. \& J.R. Dixon. 1994. Geographic variation and systematic of the striped whipsnakes (Masticophis taeniatus complex; Reptilia: Serpentes: Colubridae). Annals of the Carnegie Museum 63:1-48.

Camper, J.D. \& J.R. Dixon. 2000. Food habits of three species of striped whipsnakes, Masticophis (Serpentes: Colubridae). The Texas Journal of Science 52:83-92. 
Diario Oficial de la Federación 2010. Norma Oficial Mexicana NOM059-SEMARNAT-2010, Protección ambiental - Especies nativas de México de flora y fauna silvestres - Categorías de riesgo y especificaciones para su inclusión, exclusión o cambio - Lista de especies en riesgo, 30 de diciembre de 2010. Disponible en: http://www.profepa.gob.mx/innovaportal/file/435/1/NOM_059_ SEMARNAT_2010.pdf. [Consultado el 24 de enero del 2019]

Ernst, C. H. \& Ernst, E.M. 2003. Snakes of the United States and Canada. Smithsonians Books. Washington, D.C., USA.

Hammerson, G.A., Lavin, P., Mendoza-Quijano, F. 2007. Masticophis schotti. The IUCN Red List of Threatened Species 2007: e.T63848A12721761. Disponible en: http://dx.doi.org/10.2305/ IUCN.UK.2007.RLTS.T63848A12721761.en. [Consultado el 24 de enero del 2019]
Heimes, P. 2016. Snakes of Mexico. Herpetofauna Mexicana. Vol I. Chimaira. Frankfurt, Germany.

Lemos-Espinal, J.A. \& Dixon, J.R. 2013. Amphibians and Reptiles of San Luis Potosí. Eagle Mountain Publishing. Eagle Mountain, Utah, USA.

Werler, J.E \& Dixon, J.R. 2000. Texas snakes, identification, distribution and natural history. University Texas Press Austin. Austin, USA.

Wilson L.D. Mata-Silva, V. \& Johnson, J.D. 2013. A conservation reassessment of the reptiles of Mexico based on the EVS measure. Amphibian \& Reptile Conservation 7:1-47. 